\title{
Desain dan Uji Coba Media Pembelajaran Video Animasi Stop Motion Berbasis Saintifik Pada Materi Ikatan Kimia
}

\author{
Atika Dwi Rahmi ${ }^{1)}$ Zona Octarya ${ }^{2)^{*}}$ \\ ${ }^{1)}$ Program Studi Pendidikan Kimia, Universitas Islam Negeri Sultan Syarif Kasim Riau ${ }^{1)}$ \\ ${ }^{2)}$ Program Studi Pendidikan Kimia, Universitas Islam Negeri Sultan Syarif Kasim Riau ${ }^{2)}$ \\ ${ }^{2)}$ zona.octarya@uin-suska.ac.id
}

\begin{abstract}
This research was instigated by the students who were not able to process the knowledge gained and the lack of learning media in the learning process. This research aimed at knowing the validity and practicality levels of Scientific based Stop Motion animation video learning media on Chemical Bond lesson, especially on Ionic and Covalent Bonding. There were five development procedure stages using Borg and Gall model - collecting information, planning, developing the product, field testing, and revising the initial form of the product. This research was administered at State Vocational High School 2 Pekanbaru. Interview, questionnaire, and documentation were used to collect the data. Scientific based Stop Motion animation video learning media developed was tested valid by the experts of media and material with $87.14 \%$ mean percentage (very valid), and it was tested practical by four Chemistry subject teachers and twelve students with $92.86 \%$ mean percentage (very practical). Based on these findings, it could be concluded that Scientific based Stop Motion animation video learning media on Chemical Bond lesson was valid and practical, so it could be done the product testing at a further stage.
\end{abstract}

Keywords : Animation Video Media, Stop Motion, Chemical Bond

This is an open access article distributed under the Creative Commons 4.0 Attribution License, which permits unrestricted use, distribution, and reproduction in any medium, provided the original work is properly cited. $₫ 2018$ by author and Universitas Negeri Padang.

\section{PENDAHULUAN}

Semakin berkembangnya zaman, setiap individu berusaha untuk meningkatkan kualitasnya masing-masing. Dunia Pendidikan merupakan salah satu bagian terpenting dalam meningkatkan kualitas suatu bangsa. Seiring dengan berkembangnya ilmu pengetahuan dan teknologi, dunia pendidikan juga dituntut untuk meningkatkan mutu pendidikan demi terciptanya sumber daya manusia yang berkualitas (Rakhmawati, dkk., 2015).

Meningkatkan kualitas pendidikan dapat dilakukan melalui proses belajar. Proses belajar merupakan suatu proses dalam kehidupan seorang individu untuk mencapai tujuan tertentu (Prasetyo, dkk., 2015). Proses pembelajaran merupakan gabungan dari proses belajar dan mengajar. Mengajar merupakan penyampaian informasi berupa pengetahuan dari fasilitator (pengajar) kepada akseptornya (penerima informasi). Sedangkan belajar adalah suatu proses untuk mendapatkan informasi tersebut (Asmara, 2015). Aktivitas antara guru dan peserta didik dalam serah terima informasi disebut dengan pembelajaran. Komponenkomponen yang dibutuhkan dalam proses pembelajaran yaitu guru, peserta didik, tujuan, materi, metode mengajar, media pembelajaran, lingkungan serta evaluasi (Putra, 2013).

Selain melalui proses belajar, pemerintah juga berusaha meningkatkan mutu pendidikan secara sistematis dengan cara mengembangkan kurikulum. Setelah mengalami beberapa kali revisi, didapatkan kurikulum yang dinamakan "Kurikulum 2013". Kurikulum 2013 didasarkan pada "suatu pengetahuan tidak bisa dipindahkan begitu saja dari pengajar (guru) kepada peserta didik". Dalam proses kognitifnya, pada pembelajaran kurikulum 2013 peserta didik harus diberikan kesempatan untuk mencari ilmu pengetahuan, mengolah, dan mengkonstruksi ilmu tersebut untuk kemudian digunakan. Pembelajaran pada kurikulum ini menggunakan suatu metode pendekatan ilmiah atau scientific approach. Pendekatan ini merupakan pendekatan dimana peserta didik menjadi pusat kegiatan. Peserta didik harus mampu mengamati, menanya, mencoba, menalar dan mengkomunikasikan ilmu pengetahuan tersebut secara mandiri (Rakhmawati, dkk., 2015).

Menurut Menurut Cahyo, pembelajaran Ilmu Pengetahuan Alam (IPA) adalah sebuah proses menemukan ilmu pengetahuan, sikap ilmiah dan cara untuk menerapkan prinsip ilmu 
pengetahuan tersebut dalam kehidupan. Jadi pembelajaran IPA tidak hanya memberikan pengetahuan berupa materi abstrak, fakta, prinsip, atau konsep saja. Salah satu jenis mata pelajaran IPA yaitu "Kimia" (Aisah, dkk., 2018).

Kimia adalah ilmu yang mempelajari tentang materi dan perubahannya. Dalam kimia, materi dijelaskan melalui sudut pandang penyusun terkecilnya (Asmara, 2015). Atom, molekul dan ion merupakan materi dasar kimia yang berukuran mikroskopis. Materi ini tidak dapat dilihat langsung menggunakan mata. Ilmu kimia saling berhubungan satu sama lain, sebagian besar materi kimia harus dipelajari secara berurutan, sehingga untuk mempelajari materi yang lebih kompleks lagi, seorang individu harus sudah memahami materi dasar terlebih dahulu. Oleh karena atom merupakan pusat kegiatan kimia, maka kesulitan yang terkait dengannya dalam pembelajaran kimia menjadi saling berkaitan dan berkelanjutan untuk semua pokok bahasannya (Kurniawati, 2018).

Seiring dengan pesatnya kemajuan teknologi banyak cara yang dapat dilakukan dalam menyampaikan ilmu pengetahuan, seperti dengan menggunakan media. Media yang dapat menampilkan ilmu pengetahuan menggunakan gambar ataupun suara (audio) disebut dengan media audio visual. Salah satu jenis media audio visual adalah video animasi. Video merupakan rangkaian gambar elektronis yang dilengkapi suara. Menggunakan video memungkinkan peserta didik melakukan pembelajaran mandiri tanpa batasan ruang dan waktu (Asmara, 2015). Mendengar melibatkan indra pendengaran, melihat melibatkan indra penglihatan. Dalam menerima dan mengolah ilmu pengetahuan, semakin banyak alat indra yang digunakan maka kemungkinan ilmu tersebut dimengerti dan diingat semakin besar (Prihantana, dkk., 2014).

Animasi stop motion merupakan suatu Teknik membuat animasi dimana objek tersebut dimanipulasi secara fisik sehingga terlihat dapat bergerak sendiri. Pergerakan objek didapatkan melalui perpindahan frame. Frame diambil dengan memfoto objek yang digerakkan sedikit demi sedikit secara berurutan (Maryanti \& Trie Kurniawan, 2017). Hasil penelitian Jocelyn Wishart menyatakan bahwa animasi ini dapat menciptakan diskusi dengan teman dalam proses pembelajaran. Permodelan animasi juga dipandang bermanfaat dalam mempresentasikan pengetahuan ilmiah untuk mendukung pembelajaran (Wishart, 2017).
Hasil penelitian Hoban menyatakan pembuatan animasi menggunakan stop motion sangat membantu dalam pembelajaran konseptual dalam sains, dimana animasi dapat diatur kecepatan penayangannya. Namun waktu pembuatan menjadi salah satu kendala dalam membuat animasi stop motion (Hoban, 2005). Video animasi stop motion dapat menampilkan penjelasan tentang ilmu kimia secara bertahap. Dalam tampilannya animasi stopmotion melibatkan indra penglihatan dan pendengaran dari peserta didik, sehingga materi yang disampaikan dapat diterima secara maksimal (Maryanti \& Trie Kurniawan, 2017).

Kurikulum 2013 menuntut peserta didik untuk mampu secara mandiri memahami pembelajaran yang ada, tetapi berdasarkan hasil pengamatan dalam proses pembelajaran kimia kelas X di SMK Negeri 2 Pekanbaru kurikulum tersebut masih sulit untuk diterapkan. Peserta didik masih belum mandiri dalam mendapatkan ilmu pengetahuan dan kurang mampu mengembangkan informasi yang diberikan guru. Hasil wawancara dengan guru kimia dan peserta didik diperoleh informasi media yang digunakan dalam mengajar materi kimia masih terbatas, namun penggunaan media seperti molimod dan video lebih meningkatkan pemahaman peserta didik.

Berdasarkan latar belakang
peneliti mengembangkan suatu media pembelajaran yang memuat pendekatan saintifik berupa video animasi stop motion. Penelitian ini bertujuan untuk mengembangkan dan menganalisis tingkat validitas dan praktikalitas "Video Animasi Stop Motion Berbasis Saintifik pada Materi Ikatan Kimia" sebagai salah satu media pembelajaran kimia.

\section{METODE PENELITIAN}

Penelitian ini termasuk salah satu jenis penelitian dan pengembangan (Research and Development). Research and Development merupakan salah satu metode penelitian yang digunakan untuk menghasilkan produk tertentu dan menguji keefektifan produk tersebut (Sugiyono, 2014). Prosedur dalam penelitian ini menggunakan model penelitian dan pengembangan Borg and Gall yang mendeskripsikan prosedur pengembangan ke dalam sepuluh tahapan (Lailatusholihah \& Kristianingrum, 2016). Borg and Gall 
menyatakan bahwa dimungkinkan untuk membatasi penelitian dalam skala kecil termasuk membatasi langkah penelitian (Emzir, 2014). Dalam pengembangan ini, tahapan penelitian diadaptasi dan disesuaikan menjadi 5 tahapan: (1) Pengumpulan Data. (2) Perencanaan. (3) Pengembangan Produk. (4) Uji Coba. dan (5) Revisi Produk.

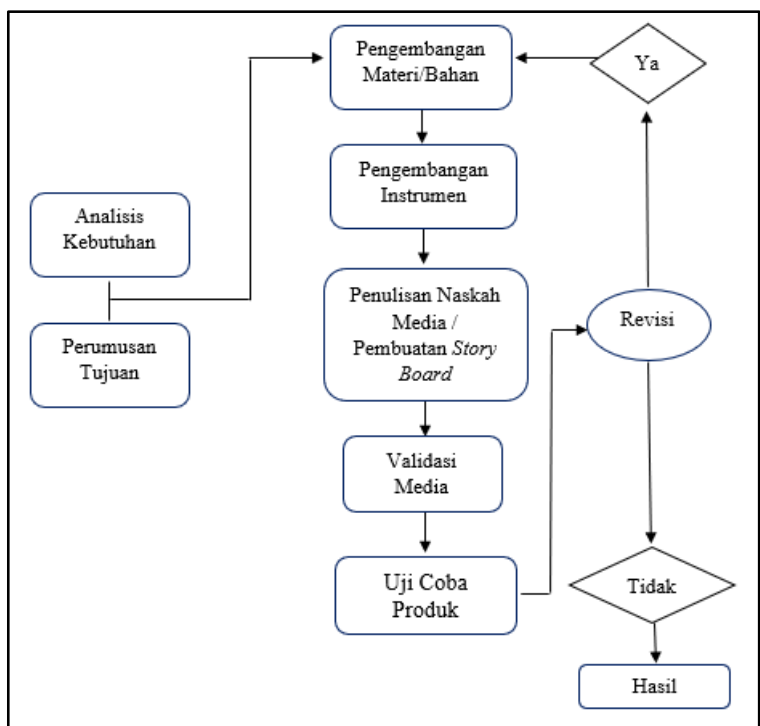

Gambar 1. Prosedur Penelitian

Pada penelitian ini dihasilkan produk berupa media pembelajaran "Video Animasi Stop Motion Berbasis Saintifik" dengan materi Ikatan Kimia. Pembuatan animasi ini dilakukan dengan pengambilan gambar berupa objek yang difoto dengan menggerakkan objek setahap demi setahap (Munir, 2013). Pada penelitian ini objek yang peneliti gunakan berupa potongan gambar kertas. Peralatan yang dibutuhkan dalam pembuatan animasi ini adalah kamera dan tripod atau alat untuk penyangga kamera (Purnasiwi \& Kurniawan, 2013). Setelah foto objek didapatkan proses editing video dilakukan menggunakan aplikasi Wondershare Filmora.

Objek yang diteliti pada penelitian adalah media pembelajaran video animasi stop motion berbasis saintifik pada pokok bahasan ikatan kimia sub bab ikatan ion dan ikatan kovalen. Subjek penelitian adalah pihak yang menilai uji validitas (ahli media dan ahli materi), uji praktikalitas (4 orang guru) dan uji respon oleh 12 orang peserta didik. Teknik pengumpulan data menggunakan dokumentasi, wawancara, dan angket. Instrumen dalam penelitian ini berupa angket uji validitas, angket uji praktikalitas dan angket uji respon peserta didik yang bertujuan untuk memperoleh informasi yang relevan. Angket berisi butir pertanyaan dan lembar masukan/saran. Angket ini menggunakan skala perhitungan Likert dengan 5 titik respon pilihan (Budiaji, 2013).

Tabel 1. Skala Angket

\begin{tabular}{cc} 
Skor & Jawaban \\
\hline 5 & Sangat Baik \\
4 & Baik \\
3 & Cukup \\
2 & Kurang Baik \\
1 & Sangat Kurang Baik \\
\hline
\end{tabular}

Sebelum diujicoba secara terbatas, terlebih dahulu produk di validasi oleh dosen ahli materi dan ahli media pembelajaran.

Teknik analisis data yang digunakan adalah:

(1) Teknik analisis deskriptif kualitatif

Teknik ini digunakan untuk mengolah data hasil review dari ahli media, ahli materi pembelajaran, guru dan peserta didik berupa saran dan masukan mengenai perbaikan.

(2) Teknik analisis deskriptif kuantitatif, digunakan untuk menganalisis hasil yang diperoleh dari angket uji validitas dan uji praktikalitas para ahli berupa angka (Riduwan, 2014).

Data yang diperoleh berupa data kualitatif yang dikuantitatifkan dengan pengukuran skala. Untuk menghitung presentase kevalidan dan kepraktisan produk digunakan rumus menghitung presentase (Riduwan, 2014).

Persentase $(\%)=\frac{\text { Skor yang diperoleh }}{\text { Skor maksimal ideal }} \times 100 \% \ldots \ldots$ (1)

Hasil presentase dari uji kevalidan dan uji kepraktisan kemudian ditafsirkan dalam pengertian kualitatif (Riduwan, 2014) berdasarkan Tabel 2 .

Tabel 2. Tabel Kriteria Hasil Uji Validitas Produk

\begin{tabular}{cc} 
Interval & Kriteria \\
\hline $81 \%-100 \%$ & Sangat Valid / Praktis \\
$61 \%-80 \%$ & Valid / Praktis \\
$41 \%-60 \%$ & Cukup Valid / Praktis \\
$21 \%-40 \%$ & Kurang Valid / Praktis \\
$0 \%-20 \%$ & Tidak Valid / Praktis \\
\hline
\end{tabular}




\section{HASIL DAN PEMBAHASAN}

Produk yang di desain dan dihasilkan dari penelitian ini berupa "Media Pembelajaran Video Animasi Stop Motion Berbasis Saintifik pada Materi Ikatan Kimia". Video ini berisi tentang materi ikatan kimia khususnya bahasan ikatan ion dan ikatan kovalen. Memiliki ukuran \pm 146 megabyte dengan berdurasi 8 menit 48 detik dan format MKV/MP4. Video ini juga dilengkapi dengan audio dan musik serta dapat ditampilkan melalui laptop, PC, juga handphone.

Video animasi stop motion berbasis saintifik ini disajikan dalam beberapa bagian yaitu, bagian pembuka, bagian isi, dan bagian penutup. Langkah-langkah pembelajaran saintifik yang mencakup 5M yaitu mengamati, menanya, mengumpulkan informasi, mengasosiasikan dan mengkomunikasikan ilmu pengetahuan (Rakhmawati, dkk., 2015) dibuat dan diselipkan pada alur cerita video. Tampilan video animasi stop motion berbasis saintifik terdapat pada Gambar 2.

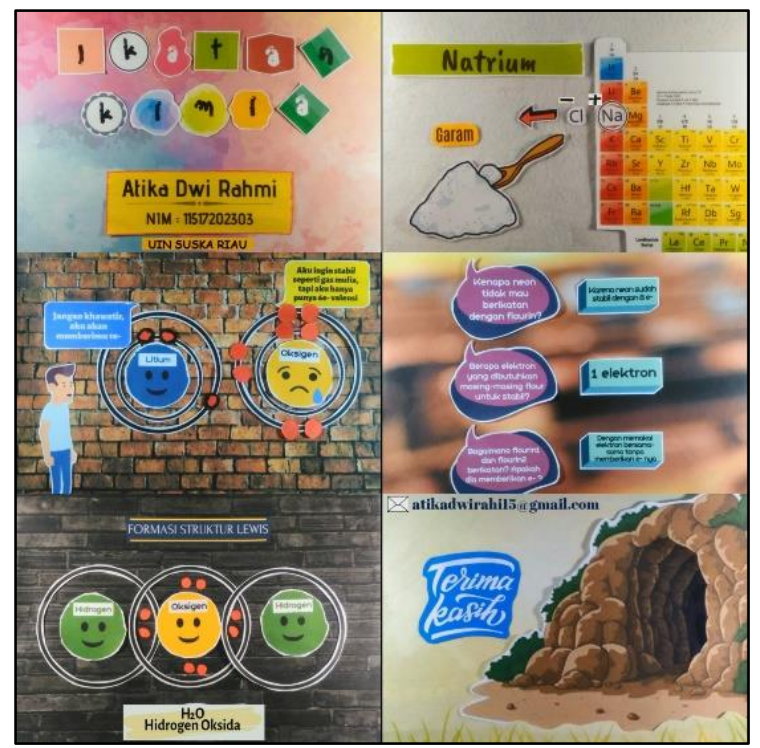

Gambar 2. Sekilas Gambaran Produk Video Animasi Stop Motion Ikatan Kimia

Pada Gambar 2 ditampilkan gambaran dari video animasi stop motion berbasis saintifik. Salah satu langkah pembelajaran yang ditampilkan yaitu mengumpulkan informasi, pada tahapan ini informasi atau konsep dari materi disajikan sedemikian rupa dan semenarik mungkin. Baik dari situasi yang diciptakan maupun dari gambar yang ditampilkan. Selain itu pada video masing-masing karakter juga dilengkapi dengan suara sehingga peserta didik dapat lebih mudah memahami dan mengumpulkan informasi mengenai materi ikatan kimia.

\section{a) Uji Validitas Materi}

Berdasarkan hasil uji validitas materi diperoleh presentase keseluruhan materi yaitu $81,43 \%$. Hasil ini dikategorikan sangat valid karena berada dalam rentang $81 \%$ - $100 \%$ (Riduwan, 2014).

Tabel 3. Masukan Ahli Materi
Tampilan

Identitas bahan ajar Perbaikan I

Penambahan audio pada indikator dan tujuan pembelajaran

Penambahan tanda $(+)$ dan (-) pada penjelasan proses pembentukan ikatan ion dan contoh
Pada Tabel 3 terdapat beberapa saran dan masukan dari dosen validator materi. Perbaikan ini dilakukan karena dalam proses pembelajaran, kemampuan setiap individu dalam memperoleh informasi berbeda-beda. Misalnya dalam belajar ada peserta didik yang lebih dominan belajar dengan visual, audio ataupun audio visual.

Tabel 4. Hasil Validasi oleh Ahli Materi

\begin{tabular}{lccc}
\multicolumn{1}{c}{ Aspek } & Skor & \% & Kriteria \\
\hline Kebenaran & 26 & $86,67 \%$ & Sangat \\
Konsep & & Valid \\
Kebahasaan & 4 & $80 \%$ & Valid \\
Keterlaksanaa & 12 & $80 \%$ & Valid \\
n & 8 & $80 \%$ & Valid \\
Tampilan & 7 & $70 \%$ & Valid \\
Pemanfaatan & 57 & $81,43 \%$ & Sangat \\
Rata-rata & Valid \\
\hline
\end{tabular}

Tabel 4 menunjukkan hasil analisis data terhadap angket validasi media pembelajaran dari validator ahli materi, skor yang didapatkan adalah 57 dari skor maksimal 70. Berdasarkan hasil perhitungan diperoleh presentase kevalidan produk yaitu $81,43 \%$ yang dikategorikan sangat valid. Materi layak untuk diujicobakan di sekolah. 


\section{b) Uji Validitas Media Pembelajaran}

Berdasarkan hasil uji validitas media diperoleh presentase keseluruhan media yaitu 92,85\% yang dikategorikan sangat valid dan layak diujicobakan karena berada dalam rentang $81 \%$ - 100\% (Riduwan, 2014). Dalam penilaian, juga terdapat beberapa saran dan masukkan dari dosen ahli media pembelajaran yang dapat dilihat pada Tabel 5 .

Tabel 5. Masukan Ahli Media

\begin{tabular}{ll}
\multicolumn{1}{c}{ Tampilan } & \multicolumn{1}{c}{ Perbaikan } \\
\hline Judul materi & Perbaiki warna judul \\
Identitas bahan & Ganti gambar kacang pada \\
ajar & $\begin{array}{l}\text { KD dengan kacang asli } \\
\text { Hilangkan penjelasan } \\
\text { contoh unsur kimia yang } \\
\text { kurang berkaitan }\end{array}$ \\
Ikatan kimia & $\begin{array}{l}\text { Penambahan tanda muatan } \\
\text { unsur pada contoh soal }\end{array}$ \\
& $\begin{array}{l}\text { Perjelas penjelasan } \\
\text { kestabilan unsur }\end{array}$ \\
Pembentukan & $\begin{array}{l}\text { Perbaiki penulisan nama } \\
\text { senyawa }\end{array}$ \\
ikatan ion & $\begin{array}{l}\text { Perbaiki penulisan istilah } \\
\text { pada soal dan pada nama } \\
\text { Soal evaluasi }\end{array}$ \\
senyawa \\
Timing & $\begin{array}{l}\text { Perbaiki timing video } \\
\text { (diperlambat) }\end{array}$ \\
Dubbing & $\begin{array}{l}\text { Sesuaikan audio dengan } \\
\text { penayangan video }\end{array}$ \\
\hline
\end{tabular}

Pada Tabel 5 dapat dilihat saran dan masukan dari dosen validator media. Perbaikan tersebut dilakukan agar gambar terlihat lebih jelas, perbaikan penulisan nama senyawa dilakukan karena pada nama senyawa seharusnya indeks letaknya lebih kecil dan tidak sama besar dengan atom. Penulisan huruf juga diseragamkan agar tidak terjadi kesalah pahaman. Seperti kata "no atom" diseragamkan menjadi "nomor atom". Selain itu pada video timing munculnya gambar dan audio banyak yang tidak sama dan perlu diperbaiki. Berikut hasil analisis data terhadap angket validasi media pembelajaran dari validator ahli media.
Tabel 6. Hasil Validasi Oleh Ahli Media

\begin{tabular}{|l|c|c|l|}
\hline \multicolumn{1}{|c|}{ Aspek } & Skor & $\%$ & Kriteria \\
\hline $\begin{array}{l}\text { Desain } \\
\text { pembelajaran }\end{array}$ & 20 & $100 \%$ & $\begin{array}{l}\text { Sangat } \\
\text { Valid }\end{array}$ \\
\hline $\begin{array}{l}\text { Keterlaksana } \\
\text { an }\end{array}$ & 5 & $100 \%$ & $\begin{array}{l}\text { Sangat } \\
\text { Valid }\end{array}$ \\
\hline $\begin{array}{l}\text { Tampilan } \\
\text { dan audio }\end{array}$ & 28 & $99,33 \%$ & $\begin{array}{l}\text { Sangat } \\
\text { Valid }\end{array}$ \\
\hline $\begin{array}{l}\text { Pemanfaatan } \\
\text { Software }\end{array}$ & 12 & $80 \%$ & $\begin{array}{l}\text { Sangat } \\
\text { Valid }\end{array}$ \\
\hline Rata-rata & 65 & $92,85 \%$ & $\begin{array}{l}\text { Sangat } \\
\text { Valid }\end{array}$ \\
\hline
\end{tabular}

Berdasarkan Tabel 6. Terlihat hasil analisis data terhadap angket validasi media pembelajaran dari validator ahli media. Skor yang didapatkan adalah 65 dari skor maksimal 70. Dari hasil perhitungan diperoleh presentase kevalidan produk yaitu $92,85 \%$ yang dikategorikan sangat valid dan media layak untuk diujicobakan ke sekolah.

\section{c) Uji Praktikalitas}

Setelah tahapan validasi produk selesai selanjutnya dilakukan uji coba kepraktisan produk. Uji coba merupakan hal yang harus dilakukan untuk mengevaluasi media pembelajaran yang telah didesain. Bagian terpenting dari penelitian dan pengembangan (research and development) adalah uji kualitas produk. Dalam penelitian pengembangan, uji kualitas produk atau hasil pengembangan meliputi uji kevalidan (validity), uji kepraktisan (practically) dan uji keefektifan (effectiveness) (Riyana, 2012). Pada penelitian ini hanya dilakukan sampai tahapan uji validitas dan praktikalitas

Uji kepraktisan dilakukan dengan memberikan video animasi stop motion berbasis saintifik pada materi ikatan kimia yang telah divalidasi oleh ahli media dan ahli materi serta lembar penilaian berupa angket kepada 4 orang guru mata pelajaran kimia adaptif dan 12 orang peserta didik di SMKN 2 Pekanbaru. Angket ini bertujuan untuk mengetahui tanggapan praktisi terhadap video animasi stop motion berbasis saintifik pada materi ikatan kimia. Pelajaran adaptif adalah pelajaran yang bukan merupakan pelajaran utama, tetapi merupakan pembelajaran yang menunjang pembelajaran produktif (Murtiningrum, dkk, 2013). 


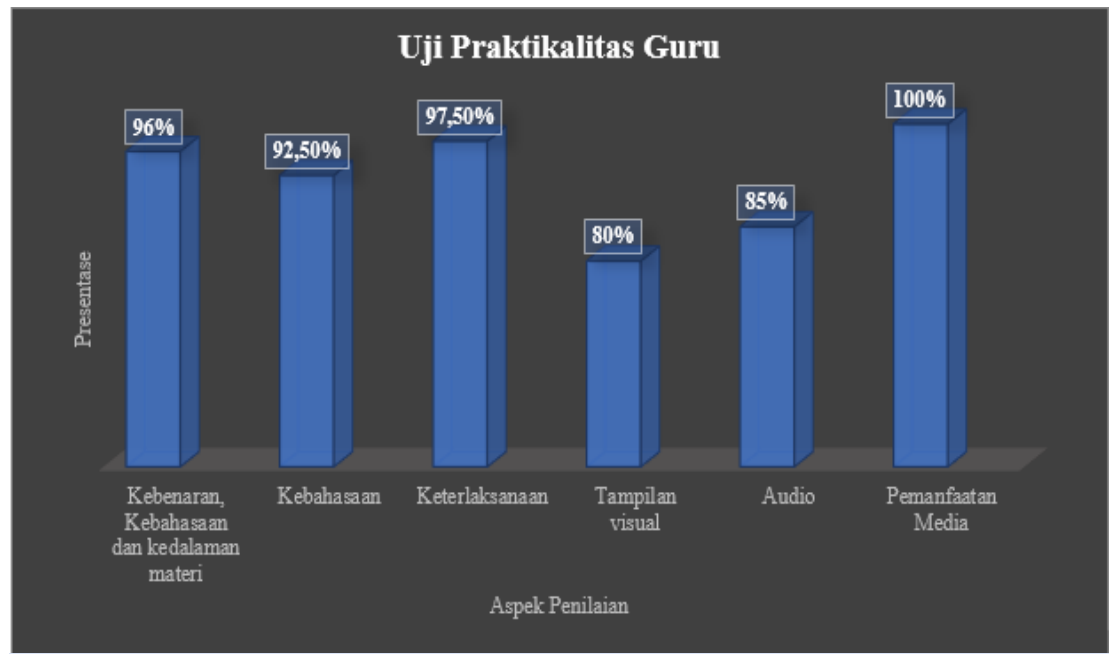

Gambar 3. Hasil Uji Praktikalitas Guru

Hasil analisis terhadap angket uji praktikalitas yang diperoleh dari 4 orang guru kimia di SMKN 2 Pekanbaru dapat dilihat pada Gambar 3. Dari 6 aspek yang dinilai yaitu Aspek Kebenaran, Kebahasaan, Keterlaksanaan,
Tampilan Visual, Audio dan Pemanfaatan Media diperoleh skor sebanyak 284 dari skor maksimal 300 , dengan nilai presentase sebesar 94,67\% dikategorikan Sangat Praktis karena terletak pada rentang 81\% - 100\% (Riduwan, 2014).

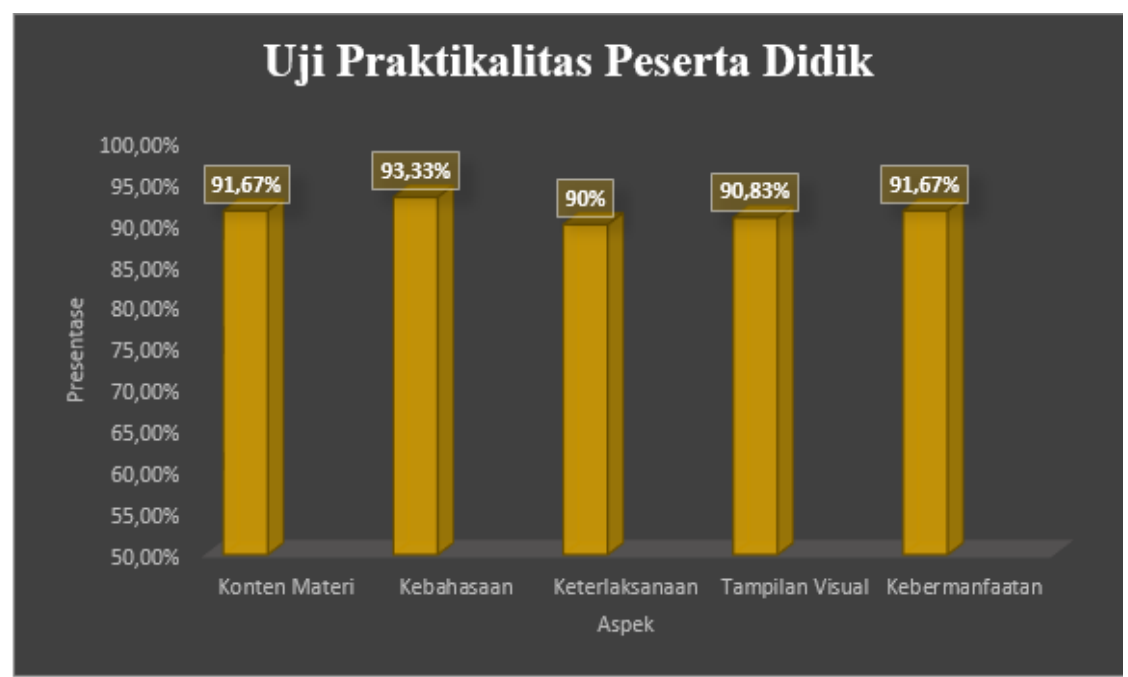

Gambar 4. Hasil Uji Praktikalitas Peserta Didik

Pada Gambar 4 hasil analisis terhadap angket uji praktikalitas yang diperoleh dari 12 orang peserta didik kelas $\mathrm{X}$ di SMKN 2 Pekanbaru, dari 5 aspek yang dinilai yaitu Aspek Konten Materi, Kebahasaan, Keterlaksanaan, Tampilan Visual, dan Kebermanfaatan diperoleh skor sebanyak 601 dari skor maksimal 660 dengan presentase 91,06\% dikategorikan Sangat Praktis karena terletak pada rentang $81 \%-100 \%$. Selain penilaian uji praktikalitas dari guru dan peserta didik, juga terdapat beberapa tanggapan dan saran dari hasil ujicoba media tersebut.

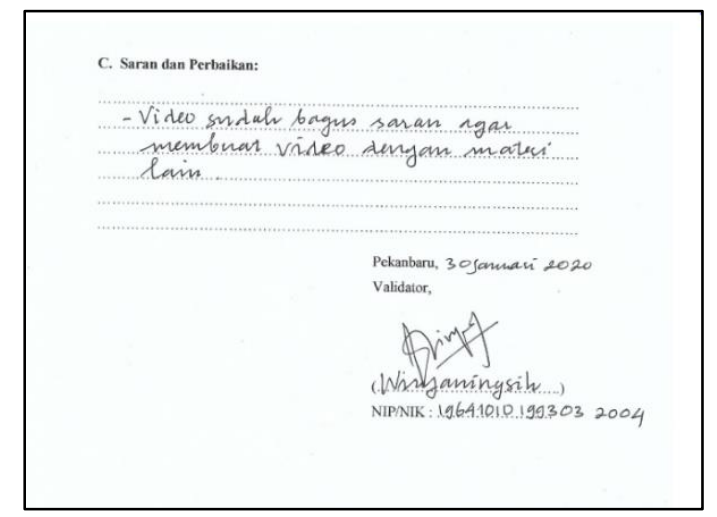

Gambar 5. Tanggapan dan Saran dari Guru 
Pada Gambar 5 tanggapan salah seorang guru terhadap video pembelajaran yang dihasilkan sudah bagus. Dan disarankan video juga dapat diterapkan pada materi lain sebagai media pembelajaran. Gambar 6 menunjukkan tanggapan peserta didik yang menyatakan agar video diperpanjang dan contoh soal diperbanyak supaya semaikin banyak ilmu yang didapatkan.

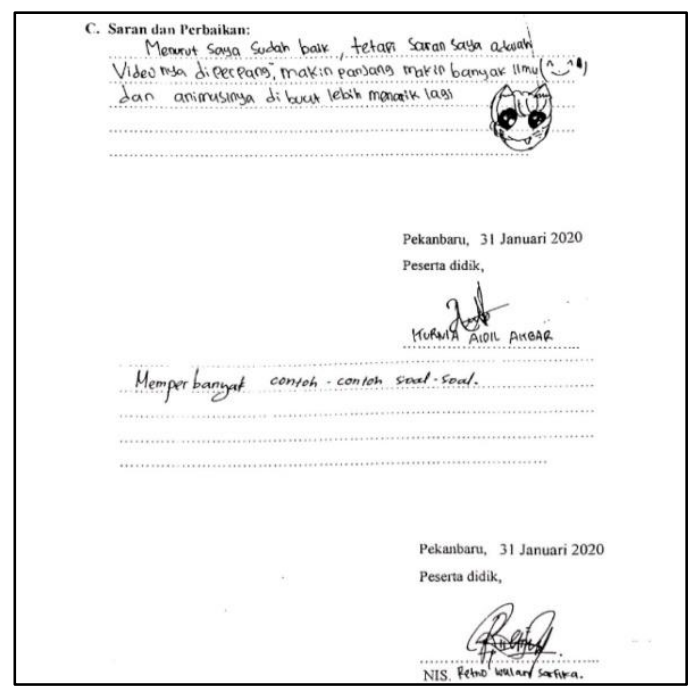

Gambar 6. Tanggapan Peserta Didik

Kelebihan media pembelajaran video animasi stop motion berbasis saintifik pada materi ikatan kimia ini antara lain:

1) Menyampaikan materi pembelajaran secara bertahap, dilengkapi dengan gambar dan suara agar mudah dipahami peserta didik.

2) Menyajikan materi pembelajaran secara jelas dan tersirat agar peserta didik dapat memahami atau menemukan sendiri pengetahuan tanpa harus bergantung atau hanya mengandalkan guru.

3) Memiliki latihan soal dan pembahasan yang akan menambah pemahaman siswa.

4) Media mudah digunakan untuk pembelajaran di kelas ataupun mandiri.

5) Media animasi stop motion berbasis saintifik yang telah dibuat memiliki ketahanan yang tinggi karena berbentuk file (Qamariah,dkk, 2017), dapat dipelajari dimanapun dan kapanpun karena bisa dioperasikan menggunakan gadget, computer, laptop dan sejenisnya.

Kelebihan yang dimiliki media ini diharapkan dapat bermanfaat untuk memfasilitasi peserta didik menambah pemahaman dalam mendapatkan ilmu pengetahuan khususnya materi kimia. Namun, media pembelajaran video animasi stop motion berbasis saintifik pada materi ikatan kimia ini baru memuat materi ikatan ion dan ikatan kovalen, sebaiknya ditambahkan lebih banyak soal latihan.

\section{KESIMPULAN}

Berdasarkan hasil dan analisis data penelitian, dapat disimpulkan bahwa media pembelajaran Video Animasi Stop Motion Berbasis Saintifik pada Materi Ikatan Kimia memiliki tingkat validitas yang sangat valid. Presentase kevalidan validasi media $92,85 \%$ dan validasi materi $81,43 \%$. Tingkat praktikalitas dari media dinyatakan sangat praktis dengan presentase uji coba praktikalitas oleh guru $94,67 \%$ dan respon peserta didik $91,06 \%$.

\section{UCAPAN TERIMAKASIH}

Penulis mengucapkan terimakasih kepada keluarga tercinta, khususnya kedua orangtua Bapak Hendrizal, SH. dan Ibu Husnida yang telah memberikan banyak dukungan. Penulis juga mengucapkan terimakasih kepada Ibu Dr. Yenni Kurniawati, M.Si. sebagai pembimbing akademik; Ibu Zona Octarya, M.Si. sebagai pembimbing; Ibu Elvi Yenti, M.Si. sebagai validator materi; Ibu Ira Mahartika, M.Pd. sebagai validator media. Ibu Ir. Wiryaningsih, Ibu Izzatul Mufidah, S.Pd., Ibu Erma Yenni, S.Pd., dan Ibu Rahmiwati, S.T., M.Pd. sebagai praktisi, siswa kelas X TKJ 2 SMKN 2 Pekanbaru tahun pelajaran 2019/2020, kakak Puteri Soraya Rajut, serta kepada teman-teman dan semua pihak yang telah membantu dalam penelitian ini.

\section{DAFTAR PUSTAKA}

Aisah, S., Kurniasih, D., \& Fitriani, F. (2018). Analisis Kemandirian Belajar Siswa pada Mata Pelajaran Kimia di Kelas X SMA Negeri 3 Sintang. Ar-Razi Jurnal Ilmiah, 6(2), 76-86. https://doi.org/ISSN. 25034448

Asmara, A. P. (2015). Pengembangan Media Pembelajaran Berbasis Audio Visual Tentang Pembuatan Koloid. Jurnal Ilmiah DIDAKTIKA, 15(2), 156-178. 
Budiaji, W. (2013). Skala Pengukuran dan Jumlah Respon Skala Likert. Jurnal Ilmu Pertanian Dan Perikanan, 2(2), 127-133. https://doi.org/ISSN 2302-6308.

Emzir. (2014). Metodologi Penelitian Pendidikan Kuantitatif dan Kualitatif. Jakarta: Rajawali Press.

Hoban, G. (2005). From claymation to slowmation: A teaching procedure to develop students' science understandings. Teaching Science, 5-12.

Kurniawati, Y. (2018). Teknik Penyusunan Instrumen Penelitian Pendidikan Kimia. Kreasi Edukasi.

Lailatusholihah, I., \& Kristianingrum, S. (2016). Pengembangan Stop Motion Chemistry Sebagai Media Pembelajaran Audio Visual Materi Laju Reaksi untuk Peserta Didik SMA/MA. Jurnal Pembelajaran Kimia, 5(3), 1-11.

Maryanti, S., \& Trie Kurniawan, D. (2017). Pengembangan Media Pembelajaran Video Animasi Stop Motion untuk Pembelajaran Biologi Dengan Aplikasi Picpac. Jurnal BIOEDUIN: Program Studi Pendidikan Biologi, 8(1), 26-33.

Munir, M. (2013). Multimedia Konsep dan Aplikasi dalam Pendidikan. Alfabeta.

Murtiningrum, T., Ashadi, A., \& Mulyani, S. (2013). Pembelajaran Kimia dengan Problem Solving Menggunakan Media ELearning Dan Komik Ditinjau Dari Kemampuan Berpikir Abstrak Dan Kreativitas Siswa. Jurnal INKUIRI, 2(3), 288-301.

Prasetyo, Y. D., Yektyastuti, R., Sholihah, M., Ikhsan, J., \& Sugiyarto, K. H. (2015). Pengaruh Penggunaan Media Pembelajaran Kimia Berbasis Android Terhadap Peningkatan Motivasi Belajar Siswa SMA. Seminar Nasional Pendidikan Sains V 2015, 252-258.

Prihantana, M. A. S., Santyasa, I. W., \& Warpala, I. W. S. (2014). Pengembangan Bahan Ajar Interaktif Berbasis Pendidikan Karakter pada Mata Pelajaran Animasi Stop Motion untuk Siswa SMK. E-Journal Program Pascasarjana Universaitas Pendidikan Ganesha, 4(1), 1-12.
Purnasiwi, R. G., \& Kurniawan, M. P. (2013). Perancangan Dan Pembuatan Animasi 2D "Kerusakan Lingkungan" dengan Teknik Masking. Jurnal Ilmiah Data Manajemen Dan Teknologi Informasi (DASI), 14(4), 54-57.

Putra, I. E. (2013). Teknologi Media Pembelajaran Sejarah Melalui Pemanfaatan Multimedia Animasi Interaktif. Jurnal TEKNOIF, 1(2), 20-25.

Qamariah, W., Daningsih, E., \& Yokhebed, Y. (2017). Kelayakan Animasi Stop Motion Pembuatan Cake Pepaya Sub Materi Peran Tumbuhan di Bidang Ekonomi. Jurnal Pendidikan Informatika Dan Sains, 6(2), 267-279.

Rakhmawati, M. D., Muhaimin, M., \& Syahri, W. (2015). Pengembangan Multimedia Pembelajaran Berbasis Scientific Approach pada Materi Larutan Elektrolit dan Non Elektrolit Menggunakan Software Adobe Flash CS6 untuk Kelas X di SMA Negeri 4 Kota Jambi. Journal of The Indonesian Society of Integrated Chemistry, 7(2), 2940.

Riduwan. (2014). Dasar-Dasar Statistika. Bandung: Alfabeta.

Riyana, C. (2012). Media Pembelajaran. Direktorat Jendral Pendidikan Islam Kementrian Agama.

Sugiyono. (2014). Metode Penelitian Pendidikan (Pendekatan Kualitatif, Kuantitatif, dan $R \& D)$. Alfabeta.

Wishart, J. (2017). Exploring How Creating Stop-Motion Animations Supports Student Teachers in Learning to Teach Science. Journal of Research on Technology in Education, 49(1-2), 88-101. 